\title{
Neonatal thymectomy reveals differentiation and plasticity within human naive T cells
}

\author{
Theo van den Broek, ${ }^{1}$ Eveline M. Delemarre, ${ }^{1}$ Willemijn J.M. Janssen, ${ }^{1}$ Rutger A.J. Nievelstein, ${ }^{2}$ Jasper C. Broen, ${ }^{1}$ Kiki Tesselaar, ${ }^{1}$ \\ Jose A.M. Borghans, ${ }^{1}$ Edward E.S. Nieuwenhuis, ${ }^{3}$ Berent J. Prakken, ${ }^{1}$ Michal Mokry, ${ }^{1,3,4}$ Nicolaas J.G. Jansen, ${ }^{5}$ and Femke van Wijk ${ }^{1}$ \\ 'Laboratory of Translational Immunology, ${ }^{2}$ Department of Radiology and Nuclear Medicine, ${ }^{3}$ Division of Pediatrics, ${ }^{4}$ Epigenomics Facility, and \\ ${ }^{5}$ Department of Pediatric Intensive Care/Pediatric Cardiothoracic Surgery, University Medical Center Utrecht/Wilhelmina Children's Hospital, Utrecht, Netherlands.
}

\begin{abstract}
The generation of naive T cells is dependent on thymic output, but in adults, the naive T cell pool is primarily maintained by peripheral proliferation. Naive T cells have long been regarded as relatively quiescent cells; however, it was recently shown that IL-8 production is a signatory effector function of naive T cells, at least in newborns. How this functional signature relates to naive $\mathrm{T}$ cell dynamics and aging is unknown. Using a cohort of children and adolescents who underwent neonatal thymectomy, we demonstrate that the naive $\mathrm{CD}^{+} \mathrm{T}$ cell compartment in healthy humans is functionally heterogeneous and that this functional diversity is lost after neonatal thymectomy. Thymic tissue regeneration later in life resulted in functional restoration of the naive $T$ cell compartment, implicating the thymus as having functional regenerative capacity. Together, these data shed further light on functional differentiation within the naive $T$ cell compartment and the importance of the thymus in human naive $T$ cell homeostasis and premature aging. In addition, these results affect and alter our current understanding on the identification of truly naive $T$ cells and recent thymic emigrants.
\end{abstract}

\section{Introduction}

After egression from the thymus, naive T cells continuously recirculate through the peripheral lymphoid tissues, surveying for their cognate antigen presented by dendritic cells. After priming, naive $\mathrm{T}$ cells differentiate into effector/memory $\mathrm{T}$ cells that can be divided into subsets based on their phenotype and function (1). The $\mathrm{CD} 4^{+} \mathrm{CD} 45 \mathrm{RA}^{+} \mathrm{CCR} 7^{+}$naive $\mathrm{T}$ cell compartment has long been regarded as merely a source for the effector/memory $\mathrm{T}$ cell population without a specific effector function. Naive CD $4^{+}$ $\mathrm{T}$ cells indeed lack substantial production of effector cytokines that define the different $\mathrm{T}$ helper subset signatures. However, it was recently shown that human naive $\mathrm{CD} 4^{+} \mathrm{T}$ cells have the unique capability of producing large amounts of IL-8 (CXCL8), indicating that these cells do have a specific effector function, at least in newborns (2). How this functional signature relates to naive $\mathrm{T}$ cell dynamics and aging is unknown.

The thymus plays a central role in the generation and maintenance of naive $\mathrm{T}$ cells early in life. After the first year of life, naive T cell production in the thymus starts to decline, resulting in a very minimal production rate in healthy adults (3-6). Even though the adult thymus is still able to produce new naive T cells $(7,8)$, we and others have shown that, in contrast to what is seen in mice, most of the naive $\mathrm{T}$ cell population in humans is maintained by homeostatic proliferation $(9,10)$. Due to increased homeostatic proliferation or decreased cell death, only a marginal decrease of the overall size of the naive $\mathrm{T}$ cell pool is observed during aging (11-15). Interestingly, new insights indicate that there are also temporal

Conflict of interest: The authors have declared that no conflict of interest exists. Submitted: October 9, 2015; Accepted: January 7, 2016.

Reference information: J Clin Invest. 2016;126(3):1126-1136. doi:10.1172/JCI84997. dynamics within the naive $\mathrm{CD} 4^{+} \mathrm{T}$ cell pool. Differential expression of $\mathrm{CD} 31$ on naive $\mathrm{CD} 4^{+} \mathrm{T}$ cells seems to distinguish between a CD $31^{+}$subset enriched in recent thymic emigrants (RTEs) and a $\mathrm{CD}^{-} 1^{-}$naive subset that has most likely arisen after homeostatic proliferation of $\mathrm{CD} 1^{+}$naive $\mathrm{CD} 4^{+} \mathrm{T}$ cells $(9,16,17)$. Indeed, the percentage of $\mathrm{CD} 31^{+}$cells in the naive $\mathrm{CD} 4^{+} \mathrm{T}$ cell compartment decreases, while the percentage of $\mathrm{CD}^{-} 1^{-}$naive $\mathrm{CD} 4^{+} \mathrm{T}$ cells increases during healthy aging (16-18). Although it is clear that both the thymus and homeostatic proliferation contribute to naive $\mathrm{T}$ cell homeostasis and that their relative contributions change over time, it remains unknown what the functional consequences are of these changes in naive $\mathrm{T}$ cell dynamics. Functional changes within the naive $\mathrm{T}$ cell compartment may have major implications for vaccination and immune intervention strategies, especially in the very young and elderly.

A unique model for studying human naive $\mathrm{T}$ cell dynamics and function is a group of patients that have undergone neonatal thymectomy during cardiac surgery. In these children, the proportion and number of both $\mathrm{CD} 4^{+}$and $\mathrm{CD} 8^{+} \mathrm{T}$ lymphocytes are significantly reduced, mainly affecting the naive $T$ cell population, which is not seen after a thymectomy later in life (19-23). Furthermore, following neonatal thymectomy, the T cell compartment composition and phenotype resemble those of an adult, which has been regarded as premature immune aging (20). Interestingly, 5 to 10 years after neonatal thymectomy, many of the thymectomized (Tx) individuals show signs of thymic tissue regrowth and restoration of $\mathrm{T}$ cell numbers and T cell receptor excision circle (TREC) content, indicating an unexpected level of thymic tissue regenerative capacity $(23,24)$. It remains unknown, however, whether this thymic tissue regeneration is functional and able to restore the affected naive $\mathrm{T}$ cell compartment and reverse changes in composition. 
A

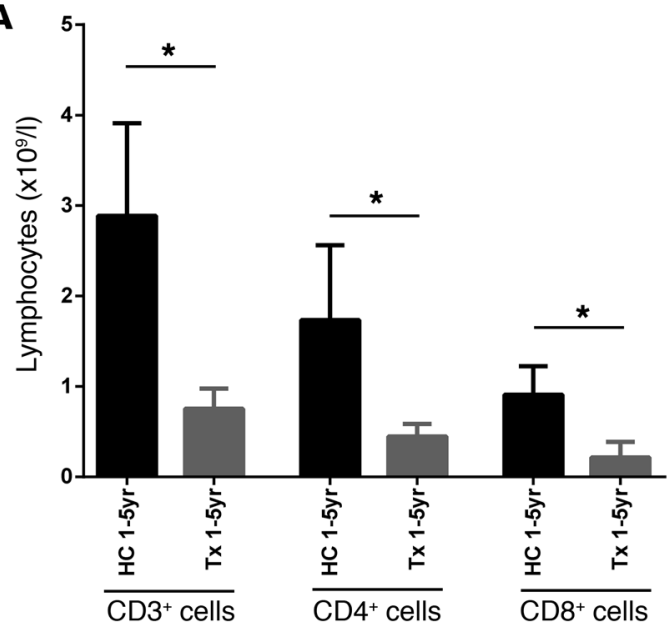

C

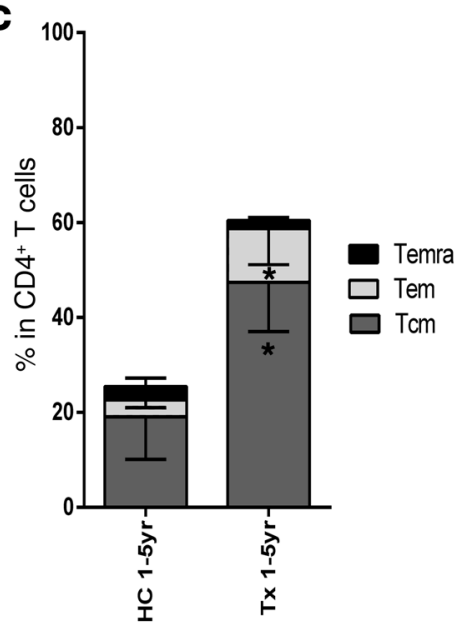

D

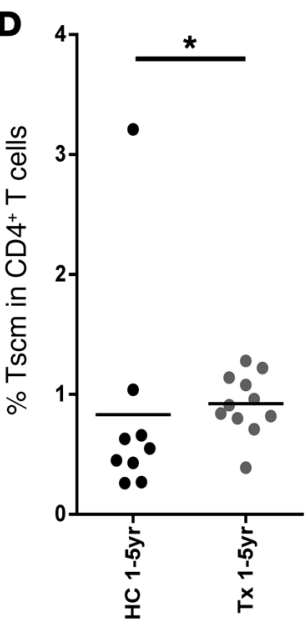

B
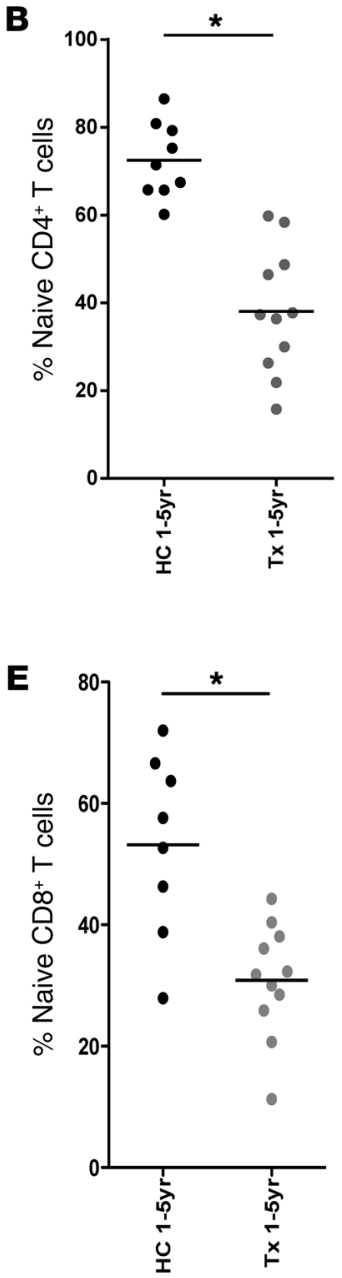

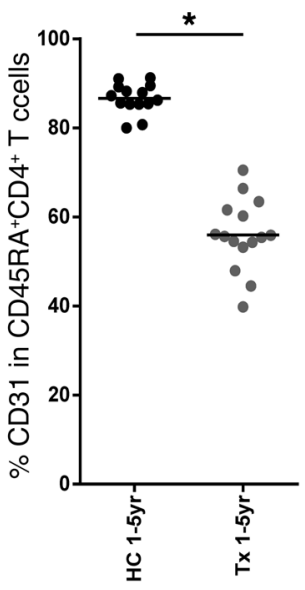

$\mathbf{F}$

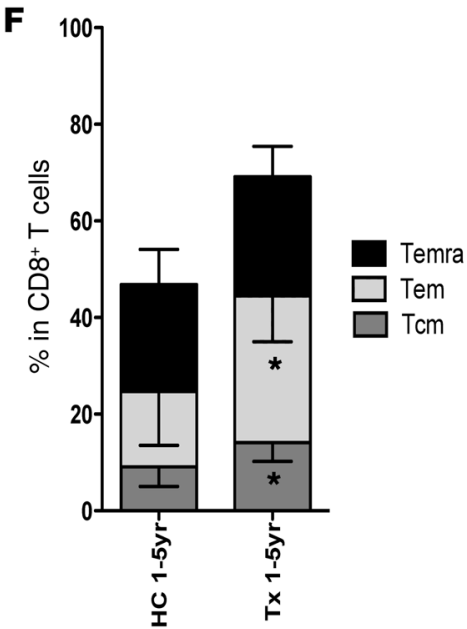

Figure 1. Neonatal thymectomy results in lower naive $\mathrm{CD4} 4^{+} \mathrm{T}$ cell percentages and skewing toward a memory phenotype in the first years (1-5 years) of life. (A) Blood lymphocyte count of $\mathrm{CD}^{+}, \mathrm{CD}^{+}$, and $\mathrm{CD} 8^{+} \mathrm{T}$ cells in $\mathrm{HCs}$ and neonatally Tx children for the age groups of 1 to 5 years. (B) Left panel, percentages of naive T cells (CD45RA+CCR7 ${ }^{+}$) within the $C D 4^{+} T$ cell population. Right panel, percentages of CD31-expressing cells among CD45RA ${ }^{+}$CD4 $^{+}$T cells. (C) Percentages of Tcm (CD45RA-CCR7 ${ }^{+}$), Tem (CD45RA-CCR7-), and Temra (CD45RA+CCR7-) in the CD4 ${ }^{+}$T cell pool. (D) Percentages of Tscm (CD45RA+CCR7 $\left.{ }^{+} C D 28^{+} C D 27^{+} F A S^{+}\right)$in the $C D 4^{+} T$ cell pool. (E) Percentages of naive $T$ cells (CD45RA $\left.{ }^{+} C C R 7^{+}\right)$within the $C D 8^{+} \mathrm{T}_{\text {cell }}$ population. (F) Percentages of Tcm (CD45RA-CCR7 $)$ ), Tem (CD45RA-CCR7-), and Temra (CD45RA ${ }^{+}$CCR7-) $^{-}$) in the CD8 ${ }^{+}$T cell pool. Black circles (or black bar, A), young HCs $(n=8-14)$; gray circles (gray bar, A), young $\operatorname{Tx}(n=10-15)$. Data are shown as mean \pm SD. See also Supplemental Figure $1 .{ }^{*} P<0.05$, Mann-Whitney $U$ test.

We utilized the unique human model of neonatal thymectomy to study naive $\mathrm{T}$ cell dynamics and the role of the thymus in early life as well as the contribution of thymic regeneration in the functional restoration of the naive $\mathrm{T}$ cell compartment. For this purpose, a cohort of children early (1-5 years) after neonatal thymectomy as well as a cohort of children at least 10 years after neonatal thymectomy were investigated. Our data indicate that the naive $\mathrm{CD} 4^{+} \mathrm{T}$ cell compartment in healthy humans is functionally more heterogeneous than previously acknowledged and that this functional diversity is severely affected by neonatal thymectomy. Furthermore, our data provide further support for the strong regenerative capacity of the thymus, leading to functional restoration of the naive $\mathrm{T}$ cell compartment after neonatal thymectomy. These data provide what we believe to be new insights in the naive $\mathrm{T}$ cell compartment that change the current concept for the identification of truly naive T cells and RTEs.

\section{Results}

Neonatal thymectomy results in significantly reduced naive $C D 4^{+} T$ cell percentages and numbers with a shift toward CD31- within the naive compartment in the first years of life. In line with our previous observations (23), we observed a significant decrease in absolute $C D 3^{+}$, $\mathrm{CD}^{+}$, and $\mathrm{CD} 8^{+} \mathrm{T}$ cell numbers in the first years after neonatal thymectomy (treatment 1-5 yr) compared with those of healthy controls (HCs) (Figure 1A). Within the $\mathrm{CD}^{+}{ }^{+} \mathrm{T}$ cell compartment, the proportion of $\mathrm{CD} 4^{+} \mathrm{CD} 45 \mathrm{RA}^{+} \mathrm{CCR} 7^{+}$naive $\mathrm{T}$ cells was significantly reduced after neonatal thymectomy, and within the naive $\mathrm{T}$ cell population, the proportion of $\mathrm{CD} 31^{+}$cells was also significantly reduced compared with that in HCs (Figure 1B). Concurrently, an increase in the fraction of both central memory $\mathrm{T}$ cells $(\mathrm{Tcm})$ and effector memory $\mathrm{CD} 4^{+} \mathrm{T}$ cells $\left(\mathrm{CD} 4^{+} \mathrm{Tem}\right)$ as present (Figure 1C), while the percentage of more differentiated Tem $\mathrm{CD} 4^{+} \mathrm{T}$ cells reexpressing CD45RA (Temra) was similar between the groups 

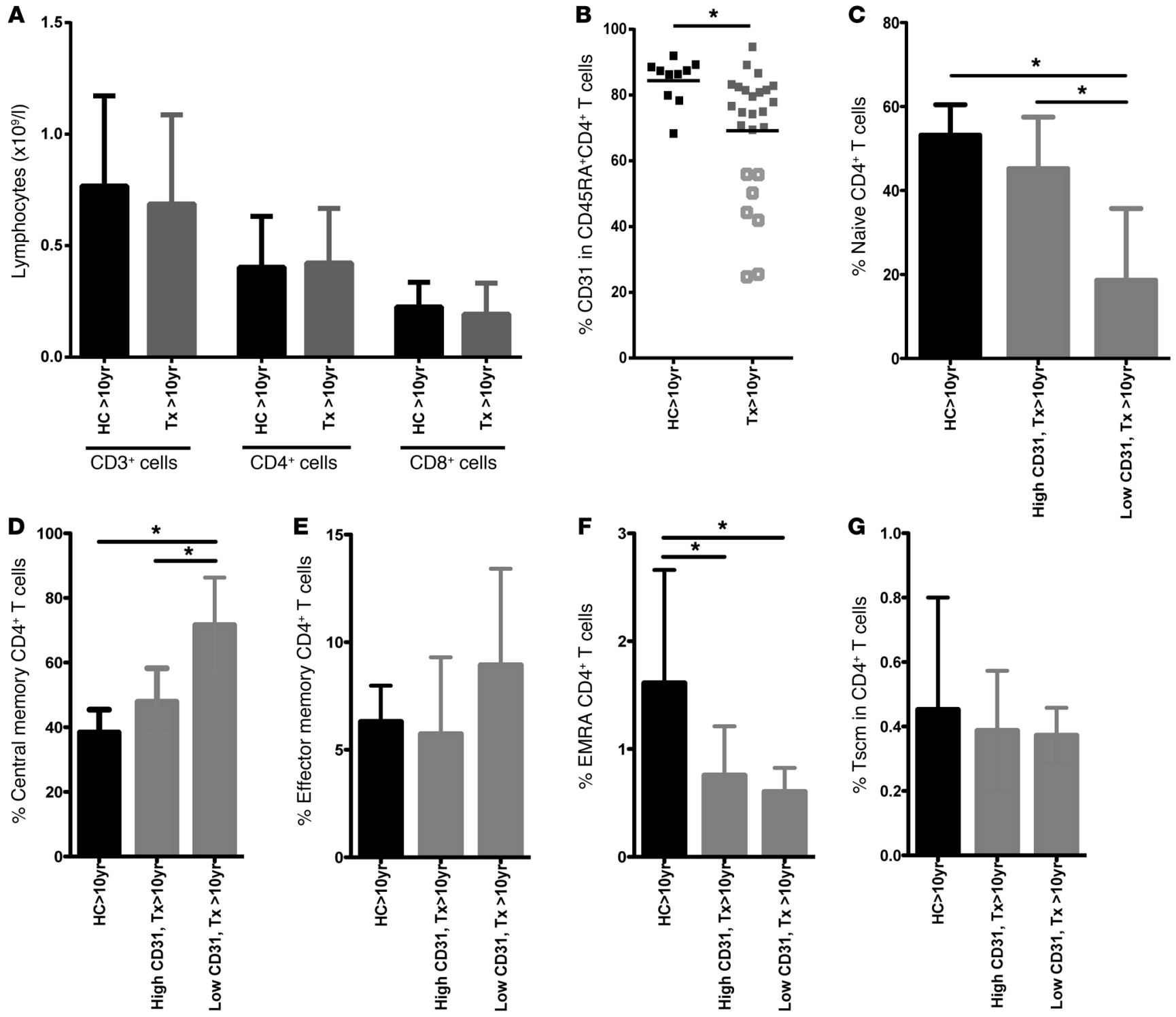

Figure 2. Thymic tissue regeneration results in restoration of the naive and effector T cell compartment later in life. (A) Lymphocyte count of CD3', $\mathrm{CD4}^{+}$, and CD8 ${ }^{+} \mathrm{T}$ cells in HCs and neonatally Tx children older than 10 years of age. (B) Percentages of CD31 expression on CD45RA ${ }^{+}$CD4 ${ }^{+} \mathrm{T}$ cells. (C) Percentages of naive T cells (CD45RA+CCR7 ${ }^{+}$) within the CD4+ $T$ cell population. (D) Percentages of Tcm (CD45RA-CCR7+). (E) Percentages of Tem (CD45RA-CCR7-). (F) Percentages of Temra (CD45RA ${ }^{+}$CCR7-). (C) Percentages of Tscm (CD45RA ${ }^{+}$CCR7 ${ }^{+}$CD28 ${ }^{+}$CD27 ${ }^{+}$FAS ${ }^{+}$) in CD4 ${ }^{+}$T cells. Black squares (or black bars), older HCs $(n=10)$; gray squares (or gray bars), older Tx patients $(n=24-26)$. Older Tx patients are further divided in high percentages of CD31 ( $n=17-19 ;$ closed gray square in B) and older TX with low CD31 percentages ( $n=7$; open gray squares in B), as described in the $x$ axis. Data are shown as mean \pm SD. See also Supplemental Figure 2. ${ }^{*} P<0.05$, Mann-Whitney $U$ test used.

(Figure 1C). In absolute numbers, both Tem and Tcm were comparable to those in HCs, while Temra were decreased (Supplemental Figure 1A; supplemental material available online with this article; doi:10.1172/JCI84997DS1). Interestingly, a relative increase in the recently described (25) self-renewing stem cell memory $\mathrm{T}$ cells (Tscm) was noted after neonatal thymectomy (Figure 1D), although their absolute numbers were still lower compared with HCs (Supplemental Figure 1A). For the $\mathrm{CD}^{+} \mathrm{T}$ cell compartment, similar differences were noted (Figure 1, E and F, and Supplemental Figure 1B) Overall, neonatal thymectomy profoundly affected the naive $\mathrm{T}$ cell compartment in numbers and composition, while absolute numbers of memory T cells were comparable in Tx and HC groups.
Thymic tissue regeneration occurs in the majority of children and results in restoration of naive $C D 4^{+} T$ cell thymic output later in life. A decade or more after neonatal thymectomy ( $\mathrm{Tx}>10 \mathrm{yr}$ ), absolute $\mathrm{CD}^{+}$and $\mathrm{CD} 8^{+} \mathrm{T}$ cell numbers were no longer different from those of age-matched HCs (ref. 23 and Figure 2A). However, we observed a subgroup of Tx patients $(n=7)$ with a very low percentage of CD31-expressing CD45RA ${ }^{+} \mathrm{CCR} 7^{+}$naive $\mathrm{CD}^{+}{ }^{+} \mathrm{T}$ cells in comparison with age-matched HCs (Figure 2B), suggesting persistent low thymic output within this subgroup. Indeed, in this subgroup of patients, lack of thymic tissue regeneration was evident based on MRI scan evaluation (data not shown). The Tx children with low CD31 also had lower T cell counts (Supplemental Figure 2A), a 

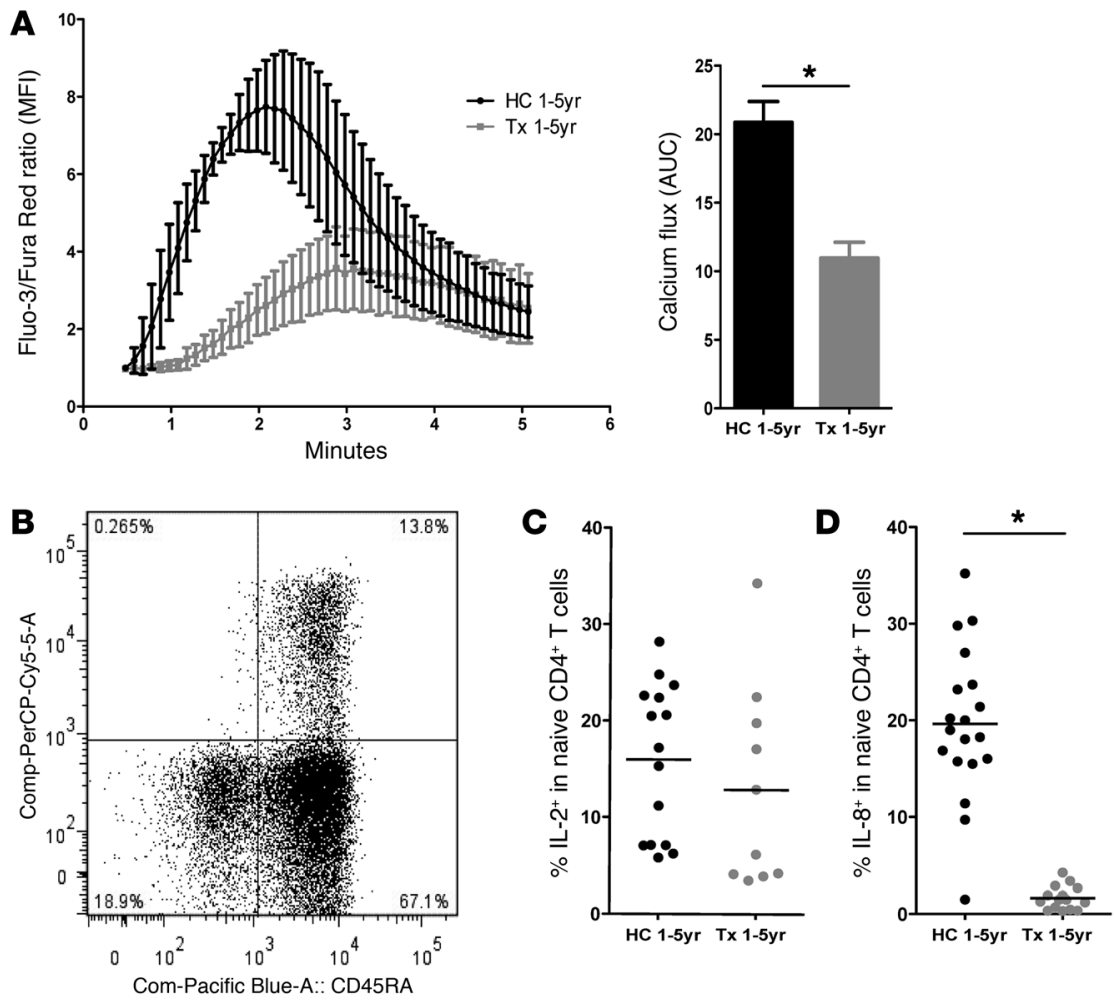

Figure 3. Naive $\mathrm{CD4}^{+} \mathrm{T}$ cell functionality is impaired after neonatal thymectomy in early life, but restores after thymic regeneration in later life. (A) Left panel, calcium flux of $\mathrm{CD} 4^{+}$naive $T$ cells in young children (young $\mathrm{HCs}, n=4$ black, young Tx, $n=6$ gray, mean \pm SD). Right panel, AUC of the calcium flux. (B) Representative dot plot of IL-8 production in CD45RA ${ }^{+} \mathrm{CD}^{+} \mathrm{T}$ cell population of young $\mathrm{HCs}$. (C) IL-2 production in naive $\mathrm{CD} 4^{+} \mathrm{T}$ cells of young HCs $(n=15)$ and young Tx patients $(n=10)$ after PMA/ion stimulation. (D) IL-8 production by naive $C D 4^{+}$T cells of young $\mathrm{HC}(n=19)$ and young Tx patient $(n=15)$ PMA/ion stimulation. (E) Left panel, calcium flux of CD4 naive $T$ cells of older HCs and Tx children. Right panel, AUC of the calcium flux ( $\mathrm{HC} 1-5 \mathrm{yr}, n=5$; high CD31, Tx $>10 \mathrm{yr}, n=6$; low CD31, Tx $>10 \mathrm{yr}, n=1$ ). (F) IL-8 production in naive CD4+ $T$ cells of older $\mathrm{HC}(n=$ 10) and Tx patient (high CD31, $n=17$; low CD31, $n=$ 7) $\mathrm{PMA}$ /ion stimulation. Data are shown as mean \pm SD. See also Supplemental Figure $3 .{ }^{*} P<0.05$, Mann-Whitney $U$ test.
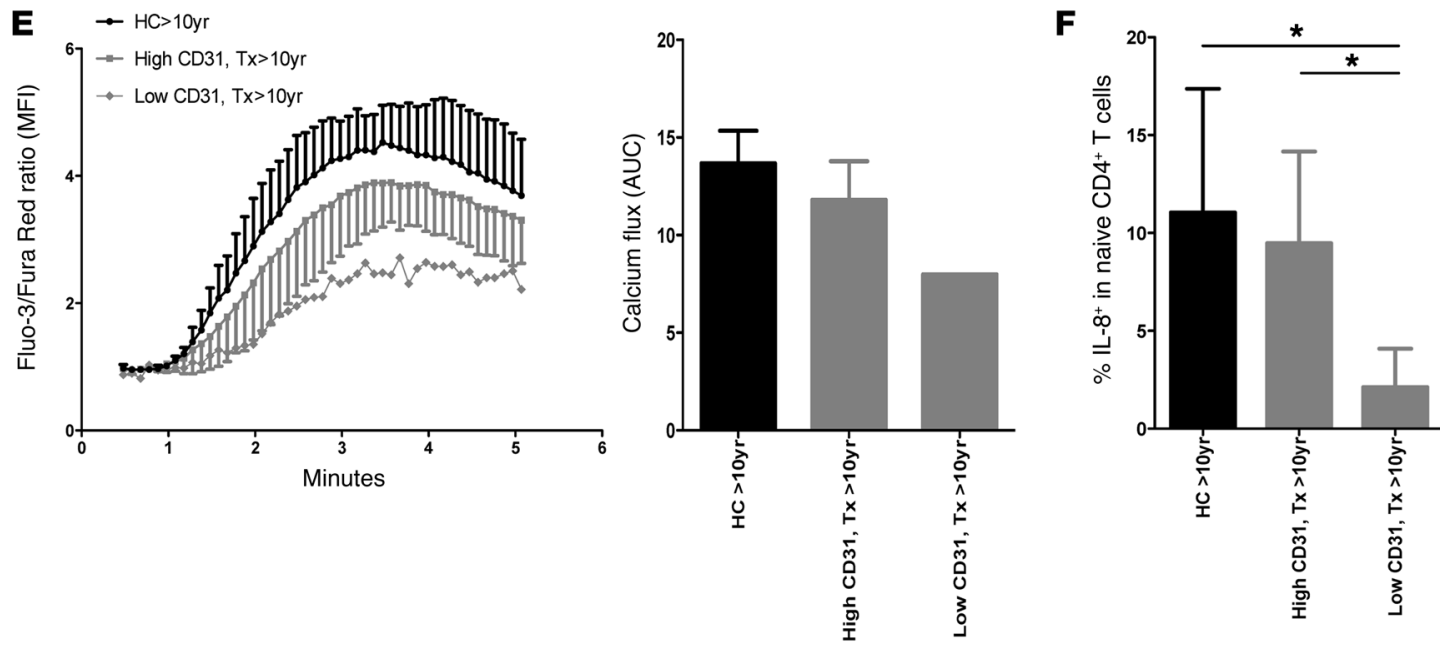

lower proportion of naive $\mathrm{CD} 4^{+} \mathrm{T}$ cells (Figure $2 \mathrm{C}$ ), a lower total naive $\mathrm{CD} 4^{+} \mathrm{T}$ cell count $\left(P<0.001,27\right.$ and $192 \times 10^{6} / 1$, median, Supplemental Figure 2B) and an increased percentage of Tcm (Figure 2D) compared with the Tx individuals with higher percentages of CD31-expressing naive CD4 ${ }^{+} \mathrm{T}$ cells. When only focusing on the subgroup of neonatally Tx children with higher CD31 percentages in their naive $\mathrm{T}$ cell pool and age-matched young adolescents, no significant differences were noted for absolute naive $\mathrm{T}$ cells and Tscm, Tcm, and Tem CD4 numbers (Supplemental Figure 2B) as well as the proportion of naive $\mathrm{T}$ cells (Figure $2 \mathrm{C}$ ), Tcm (Figure 2D), Tem (Figure 2E), and Tscm (Figure 2G) compared with agematched HCs. Similar data were obtained for $\mathrm{CD} 8^{+} \mathrm{T}$ cells, except for a proportional increase in $\mathrm{CD}^{+} \mathrm{Tem}$ and no difference in $\mathrm{CD}^{+}$ Temra, as seen for $\mathrm{CD}^{+} \mathrm{T}$ cells (Supplemental Figure 2, C and D).
Thus, although functional thymic tissue regeneration and restoration of the naive $\mathrm{CD} 4^{+} \mathrm{T}$ cell compartment after neonatal thymectomy occur in the majority of children in later life, a subgroup of Tx children show no signs of restoration of thymic output.

Naive T cell function is impaired after neonatal thymectomy, but is restored with thymic tissue regeneration in later life. As the naive $\mathrm{CD} 4^{+}$ $\mathrm{T}$ cell compartment is greatly altered after neonatal thymectomy, we next investigated functional characteristics of the remaining $\mathrm{CD} 4^{+}$naive $\mathrm{T}$ cells. Following TCR triggering, naive $\mathrm{CD} 4^{+} \mathrm{T}$ cells normally show strong calcium fluxes, higher than those found in memory T cells (ref. 26 and Supplemental Figure 3A). When we compared calcium fluxes following CD3 engagement in naive $\mathrm{CD} 4^{+} \mathrm{T}$ cells there was a striking, significant decrease in the calcium flux in the cells derived from young Tx patients compared 

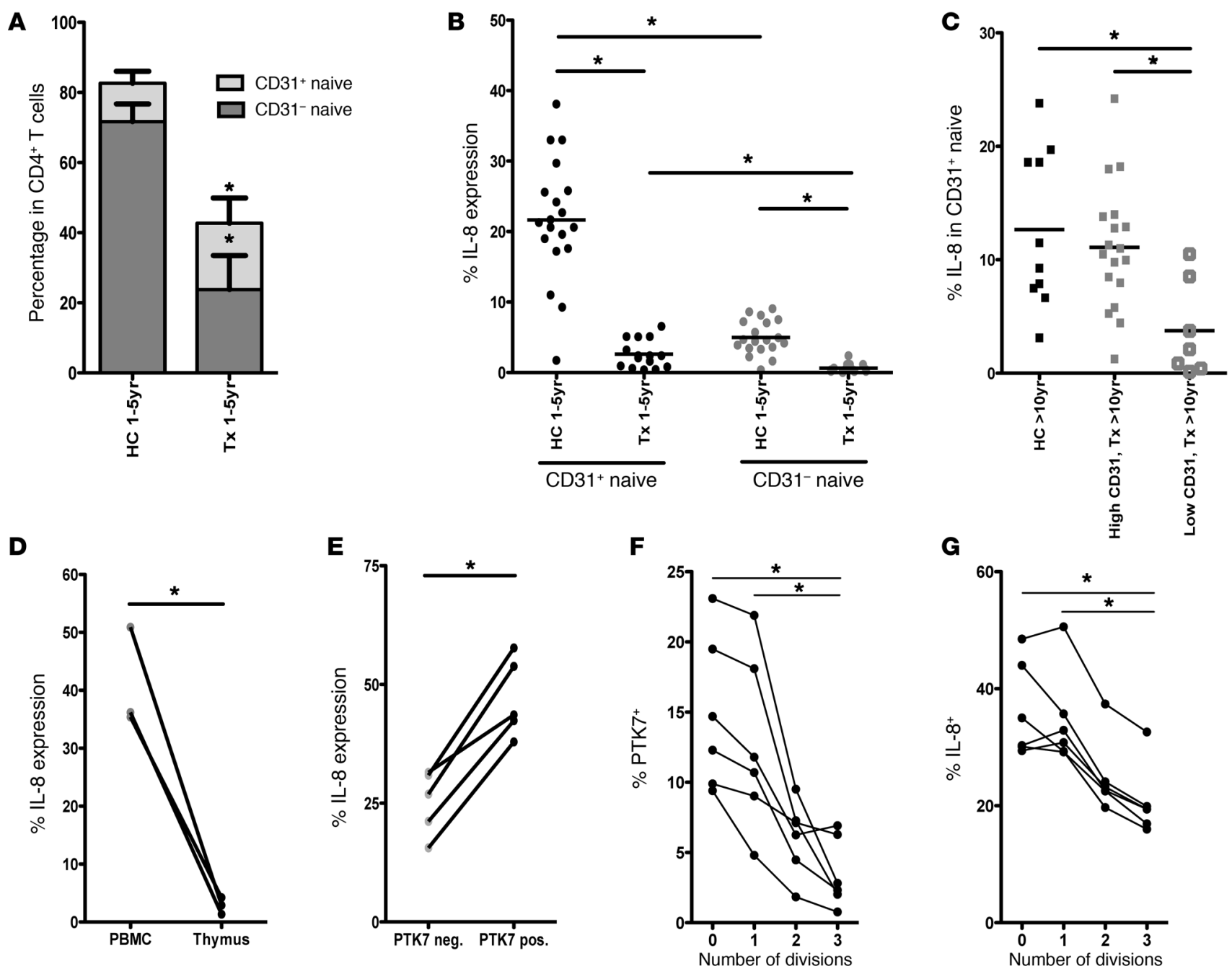

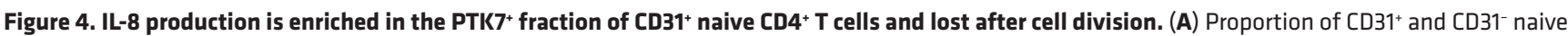
CD4 ${ }^{+}$T cells in the CD4 ${ }^{+}$T cell compartment of HCs, $1-5 \mathrm{yr}(n=19)$ and Tx patients, $1-5 \mathrm{yr}(n=15)$. (B) Expression of IL-8 by CD31+ and CD31- naive CD4 $4^{+}$T cells of young HCs $(n=19)$ and Tx patients $(n=15)$. (C) Expression of IL-8 by CD31+ and CD31- naive CD4+ T cells of older HCs $(n=10)$ and older Tx patients separated

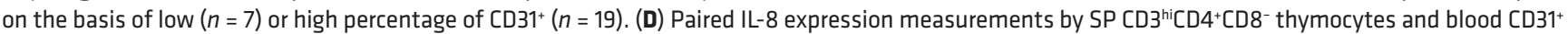
naive CD4+ T cells (PBMCs) from the Tx neonates $(n=3)$. (E) IL-8 expression by PTK7+ (black dots) and PTK7- (gray dots) CD31+ naive CD4 ${ }^{+}$T cells from young HCs $(n=5)$. (F) PTK7 expression after each cell division following cytokine stimulation of FACS-sorted CD31+ naive CD4+ $T$ cells from older HCs $(n=6)$. (C) IL-8 expression after each cell division following cytokine stimulation of FACS-sorted CD31+ naive CD4+ $\mathrm{T}$ cells from older HCs $(n=6)$. Data are shown as mean \pm SD. See also Supplemental Figures 4 and $5 .{ }^{*} P<0.05$, Mann-Whitney $U$ test for unpaired data and Wilcoxon's signed rank test for paired data.

with HCs (Figure 3A). Since there was no significant difference in peak calcium flux following addition of ionomycin (Supplemental Figure 3B), this difference could not be attributed to the differences in maximal fluxing capacity. To translate these findings of lower calcium fluxes to possible functional differences, we measured ex vivo cytokine production by the naive $\mathrm{CD} 4^{+} \mathrm{T}$ cells. It has been recently reported that naive $\mathrm{T}$ cells from newborns are, in addition to producing IL-2, capable of producing vast amounts of IL-8. In analogy with newborns, we found significant IL-8 production restricted to the naive $\mathrm{CD} 45 \mathrm{RA}^{+} \mathrm{CD} 4^{+} \mathrm{T}$ cells in young $\mathrm{HCs}$ (Figure $3 \mathrm{~B})$. While there was no difference in IL-2 production (Figure $3 \mathrm{C}$ ), naive $C D 45 \mathrm{RA}^{+} \mathrm{CD} 4^{+} \mathrm{T}$ cells of young Tx patients showed a significant decrease in IL-8 production in comparison with age-matched HCs (Figure 3D). Together, these data indicate an altered function of naive $\mathrm{CD} 4^{+} \mathrm{T}$ cells in the early years after neonatal thymectomy.
We next studied whether functionality of the naive $\mathrm{CD} 4^{+}$ $\mathrm{T}$ cell was regained with thymic tissue regeneration later in life. In the older Tx group ( $\mathrm{Tx}>10 \mathrm{yr}$ ), with higher CD31 percentages, we indeed observed restored calcium fluxes (Figure 3E) and IL-8 production of naive $\mathrm{T}$ cells in the majority of children compared with age-matched HCs (Figure 3F). While IL-8 production decreased with age, the capability of naive $\mathrm{CD} 4^{+} \mathrm{T}$ cells to produce IL-8 actually was higher in the older Tx group than in the young Tx group ( $P<0.0001 ; 6.39 \%$ vs. $1.46 \%$ median, respectively) supporting functional rejuvenation of the naive $\mathrm{T}$ cell compartment. In patients with a persistence of low percentages of CD31-expressing $\mathrm{CD}^{+}$naive T cells, a lower calcium flux persisted (Figure $3 \mathrm{E}$ ) as did decreased IL-8 production (Figure $3 \mathrm{~F}$ ). These data indicate that the thymus is not only necessary for maintaining naive T cell numbers, but also for functional restoration of the naive T cell compartment. 
A

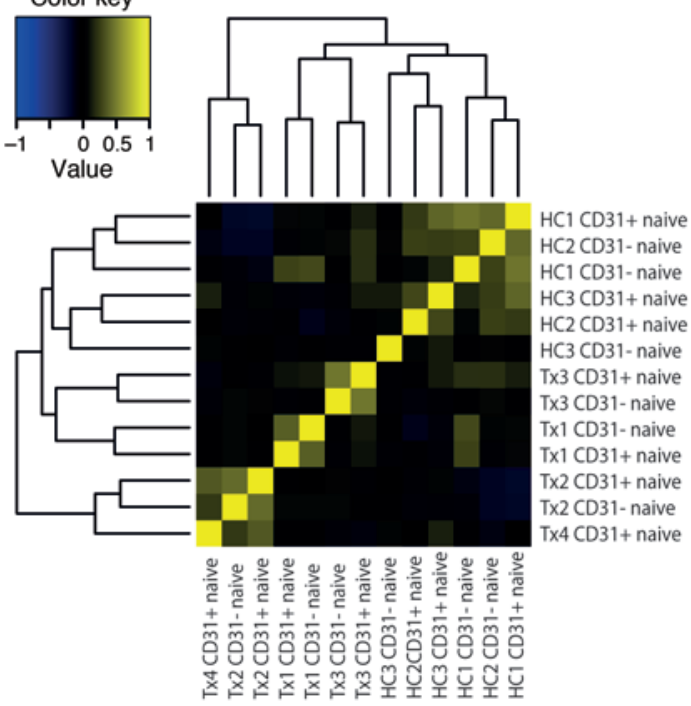

B

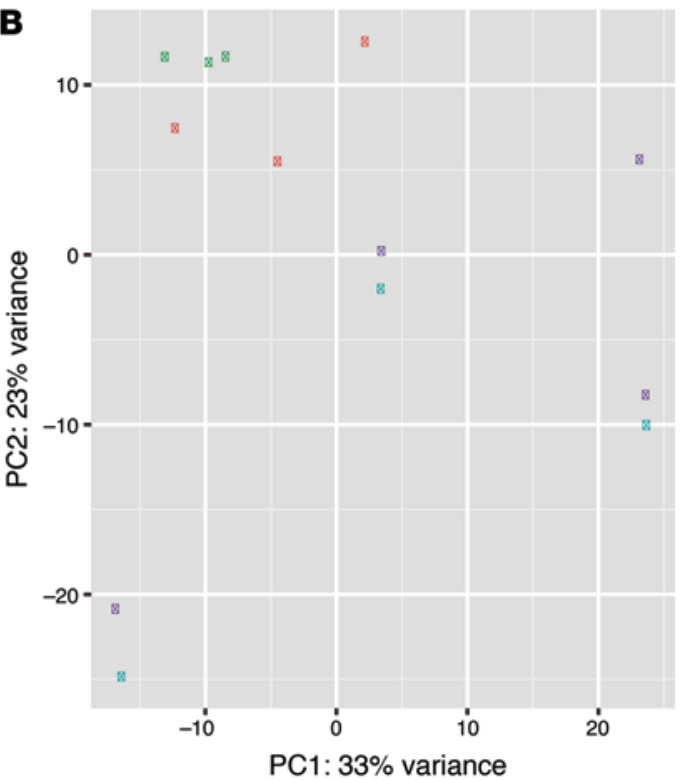

Group

\& $\mathrm{HCCD} 31$ - naive

$8 \mathrm{HCCD} 31+$ naive

$8 \mathrm{Tx} C D 31$ - naive

8 TxCD $31+$ naive

Figure 5. Functional differentiation within $\mathrm{CD} 1^{+}$naive $\mathrm{CD} 4^{+} \mathrm{T}$ cells is lost after neonatal thymectomy. (A) Correlation clustering of $\mathrm{CD} 31^{+}$and $\mathrm{CD} 31^{-}$naive $\mathrm{CD}^{+}$T cells of young HCs $(n=3)$ and young Tx patients $(n=4)$. Yellow indicates high positive correlation, while blue indicates high negative correlation. (B) Principal component analysis of CD31+ and CD31- naive T cells of young HCs $(n=3)$ and young Tx patients $(n=4)$. See also Supplemental Figures 6 and 7 and Supplemental Tables 1-3.

Neonatal thymectomy induces the loss of IL-8 expression within the $C D 31^{+}$naive $C D 4^{+} \mathrm{T}$ cell compartment. The naive $\mathrm{T}$ cell compartment can be divided based on CD31 expression. The CD31 ${ }^{+}$ fraction is thought to be enriched for RTEs and to represent the "true naive" cells with little or no peripheral proliferative history $(16,17,27)$, but little is known about the functional differentiation between the $\mathrm{CD} 1^{+}$and $\mathrm{CD} 31^{-}$naive $\mathrm{CD} 4^{+} \mathrm{T}$ cell subset. In young Tx children, a significant decrease in the percentage of $\mathrm{CD} 31^{+}$ and an increase in the percentage of $\mathrm{CD} 31^{-}$naive $\mathrm{CD} 4^{+} \mathrm{T}$ cells in the $\mathrm{CD}^{+} \mathrm{T}$ cell compartment was observed compared with that in HCs (Figure 4A). In young HCs, expression of IL- 8 by naive $\mathrm{CD} 4^{+} \mathrm{T}$ cells was largely confined to the $\mathrm{CD} 31^{+}$naive $\mathrm{CD} 4^{+} \mathrm{T}$ cell fraction (Figure $4 \mathrm{~B}$ ) and strongly reduced in both the $\mathrm{CD} 31^{+}$and $\mathrm{CD}^{-} 1^{-}$naive $\mathrm{T}$ cell compartments of young Tx children (Figure $4 \mathrm{~B})$. The loss of IL-8 in young Tx children was accompanied by an increase in IFN- $\gamma$ expression (Supplemental Figure 4). The CD31 naive $\mathrm{CD} 4^{+} \mathrm{T}$ cell fraction had an overall higher IFN- $\gamma$ expression compared with the CD $31^{+}$fraction of both the Tx and HC group, but $\mathrm{CD} 31^{+}$naive $\mathrm{T}$ cells of young Tx children had a significantly higher expression of IFN- $\gamma$ compared with age-matched HCs (Supplemental Figure 4). In older Tx patients, restoration of functional thymic tissue resulted in the restoration of IL-8 production by $\mathrm{CD} 31^{+}$naive $\mathrm{CD} 4^{+} \mathrm{T}$ cells compared with $\mathrm{HCs}$ and was even higher than in young Tx patients, while in older Tx patients with low $\mathrm{CD}^{+} 1^{+}$naive $\mathrm{T}$ cell numbers, no such restoration was seen (Figure $4 \mathrm{C}$ ). Together, these data indicate that $\mathrm{CD} 31^{+}$naive $\mathrm{CD} 4^{+}$ $\mathrm{T}$ cells are the main producers of IL- 8 and that the production is dependent on (recent) thymic output.

To investigate the time frame in which naive $\mathrm{T}$ cells start to express IL-8, we analyzed IL-8 expression by single-positive (SP) $\mathrm{CD}^{+}$thymocytes of neonates. We found very low expression of IL-8 in SP thymocytes compared with their peripheral naive
$\mathrm{CD} 1^{+} \mathrm{CD} 4^{+} \mathrm{T}$ cell counterparts (Figure $4 \mathrm{D}$ ), suggesting that IL-8 expression is initiated shortly after egress from the thymus or limited to the low number of cells that are about to exit. The expression of PTK7 on $\mathrm{CD} 31^{+}$naive $\mathrm{CD} 4^{+} \mathrm{T}$ cells has been identified as a marker of RTEs that have very recently left the thymus (28). While these cells have been regarded as quiescent, we found a significant enrichment of IL-8 production within the PTK7-positive fraction of peripheral $\mathrm{CD} 1^{+}$naive $\mathrm{CD} 4^{+} \mathrm{T}$ cells (Figure 4E and Supplemental Figure 5A), confirming the very early expression of IL-8. To further assess the correlation of IL-8 production by PTK $7^{+}$RTE, we stimulated $\mathrm{CD} 31^{+}$naive T cells in vitro with a cocktail of cytokines that are known to decrease PTK7 expression (28). With each cell division, a decrease of PTK7 expression was observed with a concomitant decrease in IL-8 production (Figure 4, F and G, and Supplemental Figure 5, B-D) At the same time, expression of CD31 remained stable after cytokine stimulation, with an increase in IFN- $\gamma$ expression per cell division (Supplemental Figure 5, E and $\mathrm{F}$, respectively). Overall, our data indicate that IL-8 production is predominantly enriched in the $\mathrm{PTK}^{+}$fraction of the $\mathrm{CD} 31^{+}$naive $\mathrm{T}$ cell compartment, and in vitro analysis suggests that this functional heterogeneity within the $\mathrm{CD} 31^{+}$naive $\mathrm{CD} 4^{+} \mathrm{T}$ cell compartment is cell division related.

$C D 31^{+}$naive $C D 4^{+} T$ cells of $T x$ children are distinct from those of HCs and resemble their CD31- naive $C D 4^{+} T$ cell counterparts. To further assess any transcriptional differences between naive $\mathrm{T}$ cells of HCs and Tx children, we performed gene-expression profiling by RNA sequencing. We analyzed the transcriptome of both FACS-sorted $\mathrm{CD}^{-} 1^{+}$and $\mathrm{CD} 31^{-}$naive $\mathrm{CD} 4^{+} \mathrm{T}$ cells from $\mathrm{Tx}$ children $(n=4$, between 1 and 5 years after Tx) and age-matched HCs $(n=3)$ (Supplemental Figure 6). Unsupervised cluster analysis showed that both $\mathrm{CD} 1^{+}$and $\mathrm{CD} 31^{-}$naive $\mathrm{CD} 4^{+} \mathrm{T}$ cell subsets of HCs did not cluster with their counterparts in Tx children (Fig- 
ure 5A). While within the group of young HCs, no specific clustering was noticed regarding both naive $\mathrm{T}$ cell subsets, in young Tx children, both the $\mathrm{CD} 31^{+}$and $\mathrm{CD} 31^{-}$naive subsets clustered together within the same patient (Figure 5, A and B). Thus CD31 naive $\mathrm{T}$ cells of $\mathrm{Tx}$ children now resembled their $\mathrm{CD}^{-}{ }^{-}$naive counterparts, indicating loss of heterogeneity. However, both naive subsets of Tx children were still distinct from the CD $31^{+}$ and CD31- naive T cell subsets of HCs and especially memory T cells of either the HC or Tx group (Figure 5B and data not shown respectively). This suggests that both naive $\mathrm{T}$ cell subsets may undergo transcriptional changes after thymic removal, leading to converging transcriptional profiles.

Transcript analyses resulted in 305 targets that significantly differed between $\mathrm{CD} 1^{+}$naive $\mathrm{CD}^{+}{ }^{+} \mathrm{T}$ cells of $\mathrm{Tx}$ children and HCs (Supplemental Table 1). In contrast, only 2 other transcripts (MAF and FAM129C), next to CD31 (PECAM-1) were found to differ between $\mathrm{CD} 31^{+}$and $\mathrm{CD} 31^{-}$naive $\mathrm{CD} 4^{+} \mathrm{T}$ cells of $\mathrm{Tx}$ children (Supplemental Table 2), while 25 transcriptional differences were present in HCs (Supplemental Table 3). This further demonstrates that, after neonatal thymectomy, $\mathrm{CD} 31^{+}$naive $\mathrm{CD} 4^{+} \mathrm{T}$ cells resemble $\mathrm{CD}^{-} 1^{-}$naive $\mathrm{CD} 4^{+} \mathrm{T}$ cells despite expression of CD31. Pathway enrichment analysis showed several pathways that were all significantly different (Supplemental Figure 7A) and all upregulated in the $\mathrm{CD} 1^{+}$naive $\mathrm{T}$ cells of Tx children, including nucleotide metabolism, cytokine signaling, apoptosis, and NF- $\kappa \mathrm{B}$ signaling, indicating a more activated and/or proliferated state of $\mathrm{CD} 31^{+}$ naive $\mathrm{CD}^{+}{ }^{+} \mathrm{T}$ cells in Tx patients compared with HCs (Supplemental Figure 7B). Together, these data indicate that there is transcriptional differentiation within the naive $\mathrm{CD} 4^{+} \mathrm{T}$ cell compartment, which is lost following neonatal thymectomy.

\section{Discussion}

Naive $\mathrm{CD}^{+} \mathrm{T}$ cells are the source of the effector/memory $\mathrm{T}$ cell compartment and are considered relatively homogeneous as opposed to the effector/memory $\mathrm{T}$ cell population. To stay truly naive, naive $\mathrm{T}$ cells have to avoid differentiation and remain relatively quiescent. With human aging, thymic output and naive $\mathrm{CD} 4^{+} \mathrm{T}$ cell numbers decline, but it has not been clear whether this is accompanied by (functional) differentiation of naive $\mathrm{T}$ cells and loss of true naivety. By utilizing a unique cohort of neonatally Tx children, we here demonstrate functional differentiation within the human naive $\mathrm{CD} 4^{+} \mathrm{T}$ cell compartment, which is lost following neonatal thymectomy. In addition, functional thymic regeneration was seen in the majority of neonatally Tx patients and resulted in restoration of functional differentiation and rejuvenation of the naive $\mathrm{CD} 4^{+} \mathrm{T}$ cell compartment, overall providing new insights in naive $\mathrm{T}$ cell dynamics that result in the better identification of "truly naive" cells and RTEs.

Heterogeneity within the naive $\mathrm{CD}^{+} \mathrm{T}$ cell compartment was already established by the expression of CD31 $(16,17)$. We now demonstrate further functional differentiation within CD $31^{+}$ naive $\mathrm{CD} 4^{+} \mathrm{T}$ cells on the basis of IL-8 production and its thymic dependence. IL-8 production was preferentially seen in the PTK7 fraction, but declined after loss of PTK7 due to cell division in vitro. While in mice, maintenance of the peripheral naive $\mathrm{T}$ cell compartment is primarily dependent on thymic output, human adults sustain naive $\mathrm{T}$ cell numbers by peripheral proliferation (9).
Several studies have suggested that even in young, HCs, a substantial proportion of naive $\mathrm{T}$ cells are derived from peripheral $\mathrm{T}$ cell renewal $(4,29)$. Thymic contribution might, however, be more prominent than initially thought, as thymic regeneration restored naive $\mathrm{T}$ cell numbers, naive $\mathrm{T}$ cell function, and phenotype, while even a decade after neonatal thymectomy, these remained altered and distinct from those of HCs in the absence of thymic regeneration. In either case, and most importantly, the thymus seems responsible for the functional differentiation of the naive $\mathrm{T}$ cells. Therefore, this study highlights that pediatric naive $\mathrm{T}$ cell function is not similar to that of adults and puts further constraints on the extrapolation of insights into naive $\mathrm{T}$ cell function from children to adults and vice versa.

Throughout life, the peripheral $\mathrm{T}$ cell pool is maintained at a relatively constant size. As thymic export stops or diminishes, the maintaining peripheral $\mathrm{T}$ cell pool proliferates, replenishing the peripheral space and gradually acquiring an effector/memory phenotype, as also seen in lymphopenic conditions and aging (8, $9,13,30)$. This slowly results in the loss of naive T cells and skewing toward the effector/memory phenotype. After neonatal thymectomy, we detected an increase in proliferation of $\mathrm{T}$ cells as well as skewing toward a Tcm and Tem phenotype, likely at the expense of naive $\mathrm{T}$ cells. Of interest, an increased proportion of a newly reported $\mathrm{T}$ cell subset (25) called Tscm is seen after neonatal thymectomy. These Tscm are suggested to be long lived and endowed with differentiation potential and self-renewal abilities, as they can generate effector/memory $\mathrm{T}$ cell subsets while preserving the original naive-like phenotype (25). Recent human in vivo analysis has suggested that relative Tscm frequencies do not vary much with age, but could increase to compensate for reduced naive $\mathrm{T}$ cell output (31). The increased Tscm compartment after neonatal thymectomy could therefore be compensatory for the reduced naive $\mathrm{T}$ cell compartment and aid in the expansion of the Tcm and Tem compartments to normal levels. Its actual contribution is, however, uncertain, as Tscm numbers are decreased in Tx children despite their increased proportion in $\mathrm{CD} 4^{+} \mathrm{T}$ cells.

During normal $\mathrm{T}$ cell activation, $\mathrm{T}$ cell antigen receptor (TCR) ligation results in rapid cytoskeletal rearrangements and a dramatic increase of intracellular calcium $\left(\mathrm{Ca}^{2+}\right)$ concentration (32). Thus, $\mathrm{Ca}^{2+}$ signaling is essential for $\mathrm{T}$ cell activation and $\mathrm{T}$ cell-dependent immune responses. After neonatal thymectomy, a drastic decrease in calcium flux was seen. Not only the height of the flux was decreased; the calcium flux was also delayed in comparison with that of HCs. The potential for an adequate calcium flux was, however, not affected, as stimulation with ionomycin resulted in an equal maximum calcium peak. In addition, $\mathrm{T}$ cell activationdependent production of IL-2 was not diminished, demonstrating that, despite an altered calcium flux response, naive $\mathrm{T}$ cells were still responsive. A delayed calcium flux response in naive $\mathrm{CD}^{+}$ $\mathrm{T}$ cells is not only apparent after neonatal thymectomy, but also with increasing age (26). This delay we observed was not due to an increased proportion of CD31- naive T cells; even though these cells do show lower calcium flux compared with the total CD4 naive $\mathrm{T}$ cell population, their calcium response was not delayed (data not shown). Together, these data indicate features reminiscent of maturation and functional differentiation within the naive $\mathrm{T}$ cell compartment after neonatal thymectomy. 
Another indication of an altered naive T cell compartment was the loss of IL-8 production that we observed in naive $\mathrm{T}$ cells of Tx children. IL-8 production has recently been revealed as a signature effector function of naive/immature $\mathrm{CD} 4^{+} \mathrm{T}$ cells in newborns. We here show that IL-8-producing naive $\mathrm{T}$ cells are also present in infants, but decline with age, as documented for adults (2). The almost complete loss of IL- 8 and concomitant increase in IFN- $\gamma$ production of naive $\mathrm{CD} 4^{+} \mathrm{T}$ cells after neonatal thymectomy indicate a functionally altered naive $\mathrm{T}$ cell compartment, resembling that of the adult immune system. While the production of IL-8 of $\mathrm{CD} 1^{+}$naive $\mathrm{CD} 4^{+} \mathrm{T}$ cells was strongly dependent on thymic presence, SP CD $4^{+}$thymocytes barely produced any IL-8. When we further subdivided the CD31+ naive population based on PTK7 expression, we found an enrichment of IL-8-positive cells within the $\mathrm{PTK}^{+} \mathrm{CD}^{2} 1^{+}$naive RTE CD $4{ }^{+} \mathrm{T}$ cells. This suggests that there is a very small window of differentiation in which IL-8 expression is induced. The loss of IL- 8 expression could be induced by a mixture of cytokines that also downregulates PTK7 (28) while maintaining CD31 expression, indicating that non-antigen-driven proliferation is sufficient to induce functional differentiation of RTEs.

CD31 has been shown to identify a compartment enriched in RTEs, whereas $\mathrm{CD}^{-} 1^{-}$naive $\mathrm{T}$ cells are thought to arise following homeostatic proliferation $(16,17)$. When comparing geneexpression profiles of $\mathrm{CD} 31^{+}$naive $\mathrm{CD} 4^{+} \mathrm{T}$ cells of both $\mathrm{HCs}$ and Tx children, large differences were found (>200 genes differentially expressed) associated with pathways in $\mathrm{T}$ cell activation. More importantly, transcriptional analysis of $\mathrm{CD}^{+} 1^{+}$and $\mathrm{CD} 31^{-}$ naive $\mathrm{T}$ cells from Tx children revealed an almost complete overlap between the 2 populations, which was not present in HCs. This demonstrates that after neonatal thymectomy, CD $31^{+} \mathrm{T}$ cells undergo differentiation toward CD31- cells without the loss of CD31, supporting the observed reduction in IL-8 production and calcium flux of naive $\mathrm{T}$ cells after thymectomy. The phenomenon of partial differentiation of naive $\mathrm{T}$ cells in aging has also been suggested based on differential expression of miRNAs (miR-181a, miR146a, and miR-21) (27) and CD25 expression on naive CD4 ${ }^{+}$ $\mathrm{T}$ cells (33). Hence, with neonatal thymectomy and with aging, naive $\mathrm{T}$ cells may acquire features of memory cells with maintenance of their naive phenotype. This partial differentiation may have detrimental consequences because the naive $\mathrm{T}$ cells seem to have lost what is essential for their function, while not having fully gained their new differentiation state. In addition, this also greatly affects our current understanding for identifying "truly naive" $\mathrm{T}$ cells and RTEs, as CD31 cells can be maintained on naive T cells even though they functionally resemble CD31- naive T cells.

While thymectomy could simply result in the gradual loss of RTE phenotypes (high IL-8 producers), multiple other factors, such as (lack of) thymic hormones, (selective) homeostatic proliferation, and an altered cytokine environment, could play a role in the altered phenotypical and functional characteristics of the naive T cell compartment following neonatal thymectomy. For instance, IL-7 plays an important role in T cell number maintenance and is used as therapy to enhance $\mathrm{T}$ cell reconstitution (34). The effects of IL-7 are most potent on RTEs, in which IL-7-mediated signaling can induce proliferation in the absence of TCR signaling $(35,36)$. We have previously shown that IL-7 is increased following thymectomy (23). We now show that cytokine stimulation can induce the loss of PTK7 and IL-8 expression in naive T cells in vitro. Hereby, IL-7 therapy could increase naive $\mathrm{T}$ cell numbers, but with the potential loss of IL-8-producing naive $\mathrm{T}$ cells within the naive $\mathrm{T}$ cell compartment. In addition, IL-7-mediated induction of $\mathrm{T}$ cell proliferation in response to low-affinity self antigens is essential for the homeostatic proliferative response observed during lymphopenia $(37,38)$. Increased (selective) homeostatic proliferation following lymphopenia has indeed been associated with increased development of autoreactivity and subsequent autoimmunity. Even though increased $\mathrm{T}$ cell proliferation is evident after thymectomy, it is still unknown whether neonatal thymectomy results in homeostatic proliferation based on self-antigen recognition and whether this differs between $\mathrm{CD} 31^{+}$and $\mathrm{CD} 31^{-}$naive T cells.

We have previously reported that, for a majority of the children, evidence of thymic tissue regeneration is observed 5 to 10 years after thymectomy (23). We assessed thymic tissue regeneration and thymic output by MRI imaging and percentage of $\mathrm{CD} 31$ in naive $\mathrm{CD} 4^{+} \mathrm{T}$ cell measurements. In a previous cohort, a similar proportion of children showed regeneration of thymic tissue assessed by MRI scan (23). However, the presence of thymic tissue does not have to indicate a functional thymus, and lack of thymic tissue cannot always be adequately determined. We therefore assessed functional thymic tissue regeneration primarily via CD31 measurement. In our cohort, all patients with lower CD31+ naive $\mathrm{T}$ cells did not show any thymic tissue on MRI, while only a small portion of children with higher CD31 did not present evident thymic tissue on MRI. While regeneration of thymic tissue was likely due to regrowth of residual thymic tissue, as it was found to be in the same location prior to thymic removal, the presence of additional cervical thymi, as has been observed in mice $(39,40)$, could not be assessed. Thymic tissue regeneration, assessed by increased percentages of $\mathrm{CD} 31^{+}$naive $\mathrm{T}$ cells, was associated with phenotypical restoration of the naive $\mathrm{T}$ cell compartment as well as functional restoration of the calcium flux and neonatal effector cytokine production of IL-8. It has been recently shown in mice that neonatal Tregs are functionally and phenotypically distinct from those produced later in life (41), indicating that there may be unknown qualitative changes in the restored naive $\mathrm{CD} 4^{+} \mathrm{T}$ cell compartment (e.g., an altered TCR repertoire). In a quarter of the children, no evidence for functional thymic tissue regeneration was detected after at least a decade. These children continued to have a disturbed phenotypical and functional naive/effector compartment, comparable to children in their first years after thymectomy. The rejuvenation capacity of the thymus is an interesting option to explore, and many interventions have been tried to restore thymic function in the elderly or in a setting of hematopoietic stem cell transplantation. Although to date, no interventions fully restore thymic function in the aging host, systemic administration of various cytokines and hormones or bone marrow transplantation have resulted in a degree of increased thymic activity and $\mathrm{T}$ cell output with age (42-45). Why thymic tissue regenerates in some children and not in others is unclear and warrants further investigation. It has been hypothesized that the age at which the thymectomy is performed might play a role in the regenerative capability later in life, as some studies with children thymectomized at an average age of 2.6 years still reported diminished naive $\mathrm{T}$ cell counts and naive $\mathrm{T}$ cell TREC contents well into the 
Table 1. Patient characteristics

$\begin{array}{lcccc} & \text { Young HCs } & \text { Young Tx } & \text { Older HCs } & \text { Older Tx } \\ \text { Number of patients } & 19 & 17 & 11 & 26 \\ \text { Age at thymectomy (d) } & - & 8(7.93) & - & 7(3.92) \\ \text { Age at blood draw (yr) } & 2.04(1.00) & 2.12(1.16) & 13.70(1.48) & 15.89(4.16) \\ \text { Sex (male) } & 13(68.4 \%) & 11(64.7 \%) & 7(63.6 \%) & 17(65.4 \%)\end{array}$

Data are shown as median \pm SD for age at of thymectomy in days and age at blood sampling in years. Numbers (percentages) are shown for male sex.

third decade of life $(19,46)$. In the current cohort, all children were thymectomized within the first month of life, and this resulted in a proportion $(73 \%)$ of thymic regeneration similar to that seen in our previous cohort (81\%), in which most children were thymectomized within the first 4 months of life (23). Besides the age of thymectomy or possible differences in soluble factors stimulating thymic regeneration, the extent of minor thymic tissue remnants may be an important factor for tissue regeneration.

In conclusion, this study shows that the thymus has a key role in the phenotypical and functional maintenance of the naive CD4 ${ }^{+}$ $\mathrm{T}$ cell population and is able to functionally regenerate later in life. We propose that thymic tissue should be preserved as much as possible during cardiac surgery, as not all children regenerated thymic tissue. Additionally, these findings give further insight in the functional heterogeneity of the naive $\mathrm{T}$ cell compartment by identifying differential IL-8 production within the $\mathrm{CD} 31^{+}$naive $\mathrm{CD} 4^{+} \mathrm{T}$ cell compartment and the dependence of this differentiation on thymopoiesis. This appreciation could aid us in better monitoring thymopoiesis and further understanding the mechanisms of naive $\mathrm{T}$ cell homeostasis after, for instance, immune ablative therapy as well as in aging.

\section{Methods}

Study design and population. Patients who had undergone complete thymectomy within the first month of life because of surgery to treat congenital heart defects at the Wilhelmina Children's Hospital were included in this study. Surgeries involving defects in the major vessels, such as transposition of the great arteries, hypoplastic left heart syndrome, and hypoplastic arch with or without coarctation of the aorta, routinely necessitate thymectomy. An overview of the study population is described in Table 1. Blood samples were taken at between 1 to 5 years (patients referred to as young Tx or Tx 1-5 yr) and after 10 years (patients referred to as older $\mathrm{Tx}$ or $\mathrm{Tx}>10 \mathrm{yr}$ ) following neonatal thymectomy, since we have previously shown that the potential to regenerate thymic tissue occurs at approximately 5 to 10 years. (23). Patients showed no clinical signs of infection at the time of inclusion nor did they have a syndrome or genetic disorder (e.g., 22q11 deletion, trisomy 21). A healthy age- and sex-matched control group (HCs) who underwent elective surgery was also included. The children were considered immunologically healthy because they did not have a history of infectious diseases or a hematologic or immunologic disorder.

Visualization of thymictissue after thymectomy. To determine whether the thymus remained absent more than 10 years after neonatal thymectomy, the presence of thymic tissue in patients was evaluated during follow-up. The presence or absence of thymic tissue on MRI scans was evaluated and scored by an experienced pediatric radiologist.
Cell preparation and flow cytometry. PBMCs were isolated from heparinized blood samples by using Ficoll Isopaque density gradient centrifugation (Amersham Pharmacia Biotech) and viably frozen and stored in liquid nitrogen until further processing. Characterization of the $\mathrm{T}$ cell compartment was performed on thawed cryopreserved PBMCs that were washed in FACS buffer (PBS containing 2\% FCS and $0.1 \%$ sodium azide) and blocked with normal mouse and rat serum. The cells were incubated in $25 \mu \mathrm{l} \mathrm{FACS}$ buffer containing the appropriately diluted antibodies. For intracellular staining of Ki-67 (B56, BD Biosciences), cells were first surface stained, followed by fixation and permeabilization according to the manufacturer's protocol. Antibodies against human CD8 (Sk-1), CD31 (WM59), CD28 (L293), CD27 (L128), FAS (CD95, clone DX2), and KI-67 (B56) were from BD Biosciences, and antibodies against CCR7 (150503) were from R\&D Systems, and CD3 (UCHT1), CD4 (RPA-T4), and CD45RA (HI100) were from BioLegend. Finally, stained mononuclear cells were washed twice in FACS buffer, run on a FACSCanto II, and analyzed by using FlowJo software (Treestar).

As cell counts and/or sufficient cells were not available for all samples due to the limited amount of blood allowed to be taken from children, some data points are not shown for all study subjects.

Calcium flux. T cells were purified from fresh PBMCs by magnetic bead separation using the biotin human T lymphocyte enrichment cocktail (BD IMag, BD Biosciences) according to the manufacturer's instructions. Purity of MACS-sorted $\mathrm{CD}^{+} \mathrm{T}$ cells was greater than $90 \%$.

500,000 MACS-isolated T cells were incubated with $0.2 \mathrm{mg} / \mathrm{ml}$ Fluo-3 and $0.4 \mathrm{mg} / \mathrm{ml}$ Fura Red (Invitrogen) for 30 minutes at $37^{\circ} \mathrm{C}$. During the last 10 minutes, a combination of the FACS antibodies CD3 (OKT3, BioLegend), CD8 (SK1, BD Bioscience), and CD45RO (UCHL1, Biolegend) was added. Cells were washed twice and resuspended in HBSS supplemented with FCS. Baseline cytosolic calcium levels were measured on a FACSCanto II flow cytometer. Next, 20 $\mu \mathrm{g} / \mathrm{ml}$ anti-IgG $\mathrm{F}\left(\mathrm{ab}^{\prime}\right)_{2}$ fragments (Jackson Immunoresearch) were added, and calcium flux was measured for 4.5 minutes. Subsequently, $0.1 \mathrm{mg} / \mathrm{ml}$ ionomycin (Calbiochem) was added. Calcium flux of CD $4^{+}$ naive $\mathrm{T}$ cells was assessed by gating on $\mathrm{CD}^{+} \mathrm{CD}{ }^{-} \mathrm{CD} 45 \mathrm{RO}^{-} \mathrm{T}$ cells and of memory $\mathrm{CD} 4^{+} \mathrm{T}$ cells on $\mathrm{CD}^{+} \mathrm{CD} 8^{-} \mathrm{CD} 45 \mathrm{RA}^{-} \mathrm{T}$ cells (CD45RA [HI100, BioLegend]), as binding of anti-IgG F( $\left(\mathrm{ab}^{\prime}\right) 2$ fragments on other fluorochromes other than $\mathrm{CD} 3$ could potentially interfere with the CD3-triggered calcium flux.

$T$ cell stimulation. 200,000 PBMCs were stimulated with PMA $(20 \mathrm{ng} / \mathrm{ml})$ and ionomycin $(1 \mu \mathrm{g} / \mathrm{ml})$ for 5 hours at $37^{\circ} \mathrm{C}$ and $5 \% \mathrm{CO}_{2}$ in culture medium (10\% hAB-serum $1 \%$ penicillin, streptomycin, and $1 \%$ L-glutamine). After 1 hour of culture, GolgiStop (BD) was added to the culture. Cells were then washed and blocked with normal mouse serum followed by extracellular staining, fixation in Cytofix/Cytoperm, and 
washing in Perm/Wash solution (Cytofix/Cytoperm Kit, BD). Finally, cells were blocked with normal rat serum and incubated with the appropriate mAbs against IL-2 (MQ1-17H12, BD Biosciences) and IL-8 (BH0814, Biolegend) for intracellular cytokine staining.

In the case of measurement of IL- 8 production in thymus (SP CD $4^{+}$ thymocytes, $\left.\mathrm{CD}^{\text {hi }} \mathrm{CD} 4^{+} \mathrm{CD} 8^{-}\right)$and $\mathrm{PBMCs}\left(\mathrm{CD} 31^{+} \mathrm{CD} 45 \mathrm{RA}^{+} \mathrm{CD} 8\right.$ $\mathrm{CD}^{+}{ }^{+} \mathrm{CD}^{+} \mathrm{T}$ cells), samples were gathered from the same neonate. Thymocytes were isolated via straining through a mesh filter; this was followed by Ficoll Isopaque density gradient centrifugation. PMA/ ionomycin stimulation was performed as described above and on fresh isolated cells.

In vitro cytokine stimulation. $\mathrm{CD} 31^{+}$naive $\mathrm{T}$ cells were FACS sorted (Supplemental Figure 6) and stained with CellTrace Violet (final concentration $2 \mu \mathrm{M}$ ) for 7 minutes at $37^{\circ} \mathrm{C}$. The reaction was stopped by adding $10 \times$ volume of cold, filtered $100 \%$ FCS. Cells were washed and plated at $50,000 \mathrm{~T}$ cells per well in culture medium, followed by stimulation with $25 \mathrm{ng} / \mathrm{ml}$ of recombinant human IL-6 (BD Biosciences - Pharmingen), IL-7 (ImmunoTools), IL-10 (ImmunoTools), IL-15 (ImmunoTools), and IFN- $\gamma$ (eBioscience) as previously described, for 6 days (28). After cytokine stimulation, cells were washed and stimulated with PMA and ionomycin as described under $T$ cell stimulation to determine IL- 8 and IFN- $\gamma$ cytokine production. PTK7 (Miltenyi Biotec, 188B) and isotype staining (Miltenyi Biotec, S43.10) were performed to assess $\mathrm{PTK}^{+}$cells in addition to CD3, CD4, CD31, and CD45RA cells.

RNA sequencing. PBMCs from neonatally Tx children (1-5 years of age, $n=4)$ and age-matched controls (1-5 years, $n=3$ ) were FACS sorted on $\mathrm{CD} 1^{+}$and $\mathrm{CD} 31^{-}$naive $\mathrm{CD} 4^{+} \mathrm{T}$ cells using the following mAbs: CD3 (clone OKT3, BioLegend), CD4 (clone RPA-T4, eBioscience), CD25 (clone BC96, BioLegend), CD45RA (clone HI100, BioLegend), CD45RO (clone UCHL1, BioLegend), CD31 (clone WM59, BioLegend), CD127 (clone eBioRDR5, eBioscience), and CCR7 (clone 150503, R\&D Systems). To ensure that no contamination of Tregs and Temra occurred, these cells were excluded according to the gating strategy depicted in Supplemental Figure 6. Sorted cells were lysed in RLTplus buffer with (1\%) $\beta$ mercaptoethanol.

Total RNA was purified from sorted $\mathrm{CD} 31^{+}$and $\mathrm{CD} 31^{-}$naive $\mathrm{CD} 4^{+}$ $\mathrm{T}$ cells using the AllPrep DNA/RNA/miRNA Universal Kit (QIAGEN) according to the manufacturer's instructions. RNA was stored at $-80^{\circ} \mathrm{C}$ until further processing. mRNA was isolated using Poly(A) Beads (NEXTflex). Sequencing libraries were prepared using the Rapid Directional RNA-Seq Kit (NEXTflex) and sequenced on Illumina NextSeq500 to produce single-end 75 base long reads (Utrecht DNA Sequencing Facility). Sequencing reads were mapped against the reference genome (hy19 assembly, NCBI37) using BWA (47) package ( mem -t 7-c 100 -M $-\mathrm{R}$ ). Reads mapping to multiple locations were excluded from the analysis. The RPKM values and the raw read numbers were calculated using the rnaseq_countgeneread function from Cisgenome v2 (48).

Statistics. Statistical significance between 2 groups was assessed using the Mann-Whitney $U$ test for unpaired data and Wilcoxon's signed rank test for paired data. In the case of the cytokine stimulation of $\mathrm{CD} 31^{+}$naive $\mathrm{CD} 4^{+} \mathrm{T}$ cells, Kruskall-Wallis test was performed (2-sided), and comparisons were considered significant at $P<0.05$ after Dunn's multiple comparison test. Differentially expressed genes were identified using the DESeq2 package with standard settings (49). Genes with $\log _{2}$ fold change larger than 0.6 , base mean greater than 10 , and $P$ value adjusted at less than 0.05 (False Discovery Rate B\&H) were considered as differentially expressed. In the correlation heat map, Pearson's correlation was used as an index of similarity. Pathway enrichment analysis was clustered by ToppFun (https://toppgene. cchmc.org/enrichment.jsp)

Accession numbers. All original microarray data were deposited in the NCBI's Gene Expression Omnibus (GEO GSE72400).

Study approval. The study was approved by the medical ethical committee of the University Medical Center Utrecht, and written consent was obtained from all study participants or their legal guardians prior to inclusion in the study in agreement with the Helsinki Declaration of 1975 (revised in 1983).

\section{Author contributions}

TVDB and FVW were responsible for conceptualization. TVDB, EMD, and FVW were responsible for methodology. Investigation was performed by TVDB and EMD. Formal analysis was performed by TVDB and MM. TVDB and FVW wrote the original draft. Resources were provided by WJMJ, MM, RAJN, EESN, and JCB. Supervision was by FVW, NJGJ, KT, JAMB, and BJP. BJP and FVW were responsible for funding acquisition.

\section{Acknowledgments}

The authors thank W.H.S. van Wijk, M.M. Driessen, J.M. Breur, and F.J. Meijboom for providing blood samples of older Tx patients (Department of Pediatric Cardiology, University Medical Center Utrecht). We thank the Utrecht DNA generation sequencing facility (http://utrecht-sequencing-facility.nl) for their support in geneexpression profiling via RNA sequencing and Noortje van den Dungen and the Epigenomics Facility for creating the library. We also would like to thank J.F. van Velzen and C.A.J. van der Burght for their expertise in FACS sorting. T. van den Broek is financially supported by the Center for Translational Molecular Medicine (CTMM) and the Dutch Arthritis Foundation, project TRACER. E.M. Delemarre is financially supported by an AGIKO grant from The Netherlands Organization for Scientific Research (NWO, ZonMw). F. van Wijk is supported by a VIDI grant from The Netherlands Organization for Health Research and Development (ZonMw).

Address correspondence to: Femke van Wijk, Laboratory of Translational Immunology (LTI), Wilhelmina Children's Hospital, University Medical Center Utrecht, Lundlaan 6, 3508 GA Utrecht. Phone: 0031.887550808; E-mail: F.vanwijk@umcutrecht.nl.
1. Zhu J, Yamane H, Paul WE. Differentiation of effector $\mathrm{CD} 4^{+} \mathrm{T}$ cell populations. Annu Rev Immunol. 2010;28:445-489.

2. Gibbons D, et al. Interleukin-8 (CXCL8) production is a signatory $\mathrm{T}$ cell effector function of human newborn infants. Nat Med. 2014;20(10):1206-1210.
3. Aspinall R, Andrew D. Thymic involution in aging. J Clin Immunol. 2000;20(4):250-256.

4. Bains I, Antia R, Callard R, Yates AJ. Quantifying the development of the peripheral naive $\mathrm{CD} 4^{+} \mathrm{T}-$-cell pool in humans. Blood. 2009;113(22):5480-5487.

5. Bains I, Thiebaut R, Yates AJ, Callard R. Quan- tifying thymic export: combining models of naive $\mathrm{T}$ cell proliferation and TCR excision circle dynamics gives an explicit measure of thymic output. J Immunol. 2009;183(7):4329-4336.

6. Flores KG, Li J, Sempowski GD, Haynes BF, Hale LP. Analysis of the human thymic perivascular space during aging. JClin Invest. 
1999;104(8):1031-1039.

7. Hazenberg MD, et al. T-cell receptor excision circle and T-cell dynamics after allogeneic stem cell transplantation are related to clinical events. Blood. 2002;99(9):3449-3453.

8. Westera L, et al. Lymphocyte maintenance during healthy aging requires no substantial alterations in cellular turnover. Aging Cell. 2015;14(2):219-227.

9. den Braber I, et al. Maintenance of peripheral naive $\mathrm{T}$ cells is sustained by thymus output in mice but not humans. Immunity. 2012;36(2):288-297.

10. Mackall CL, Gress RE. Thymic aging and T-cell regeneration. Immunol Rev. 1997;160:91-102.

11. Bertho JM, Demarquay C, Moulian N, Van Der Meeren A, Berrih-Aknin S, Gourmelon P. Phenotypic and immunohistological analyses of the human adult thymus: evidence for an active thymus during adult life. Cell Immunol. 1997;179(1):30-40.

12. Douek DC, et al. Changes in thymic function with age and during the treatment of HIV infection. Nature. 1998;396(6712):690-695.

13. Goldrath AW, Bevan MJ. Selecting and maintaining a diverse T-cell repertoire. Nature. 1999;402(6759):255-262.

14. Jamieson BD, et al. Generation of functional thymocytes in the human adult. Immunity. 1999;10(5):569-575.

15. Wertheimer AM, et al. Aging and cytomegalovirus infection differentially and jointly affect distinct circulating T cell subsets in humans. J Immunol. 2014;192(5):2143-2155.

16. Kilpatrick RD, et al. Homeostasis of the naive $\mathrm{CD}^{+} \mathrm{T}$ cell compartment during aging. J Immunol. 2008;180(3):1499-1507.

17. Kimmig $\mathrm{S}$, et al. Two subsets of naive $\mathrm{T}$ helper cells with distinct $\mathrm{T}$ cell receptor excision circle content in human adult peripheral blood. J Exp Med. 2002;195(6):789-794.

18. Kohler S, et al. Post-thymic in vivo proliferation of naive $\mathrm{CD} 4^{+} \mathrm{T}$ cells constrains the TCR repertoire in healthy human adults. Eur J Immunol. 2005;35(6):1987-1994.

19. Prelog M, et al. Thymectomy in early childhood: significant alterations of the CD4(+)CD45RA(+) CD62L $(+) \mathrm{T}$ cell compartment in later life. Clin Immunol. 2009;130(2):123-132.

20. Sauce D, et al. Evidence of premature immune aging in patients thymectomized during early childhood.J Clin Invest. 2009;119(10):3070-3078.

21. Schadenberg AW, et al. Differential homeostatic dynamics of human regulatory T-cell subsets following neonatal thymectomy. J Allergy Clin Immunol. 2014;133(1):277-280.

22. Sempowski G, et al. Effect of thymectomy on human peripheral blood $\mathrm{T}$ cell pools in myasthenia gravis. J Immunol. 2001;166(4):2808-2817.

23. van Gent $R$, et al. Long-term restoration of the human T-cell compartment after thymectomy during infancy: a role for thymic regeneration? Blood. 2011;118(3):627-634.

24. Rodewald HR. Thymus organogenesis. Annu Rev Immunol. 2008;26:355-388.

25. Gattinoni L, et al. A human memory T cell subset with stem cell-like properties. Nat Med. 2011;17(10):1290-1297.

26. Roederer M, Bigos M, Nozaki T, Stovel RT, Parks DR, Herzenberg LA. Heterogeneous calcium flux in peripheral $\mathrm{T}$ cell subsets revealed by five-color flow cytometry using log-ratio circuitry. Cytometry. 1995;21(2):187-196.

27. Goronzy JJ, Fang F, Cavanagh MM, Qi Q, Weyand $\mathrm{CM}$. Naive $\mathrm{T}$ cell maintenance and function in human aging. JImmunol. 2015;194(9):4073-4080.

28. Haines $\mathrm{CJ}$, et al. Human $\mathrm{CD}^{+} \mathrm{T}$ cell recent thymic emigrants are identified by protein tyrosine kinase 7 and have reduced immune function. J Exp Med. 2009;206(2):275-285.

29. Hazenberg MD, et al. Establishment of the $\mathrm{CD}^{+} \mathrm{T}$-cell pool in healthy children and untreated children infected with HIV-1. Blood. 2004;104(12):3513-3519.

30. Freitas AA, Rocha B. Population biology of lymphocytes: the flight for survival. Annu Rev Immunol. 2000;18:83-111.

31. Biasco $\mathrm{L}$, et al. In vivo tracking of $\mathrm{T}$ cells in humans unveils decade-long survival and activity of genetically modified T memory stem cells. Sci Transl Med. 2015;7(273):273ra13.

32. Lewis RS. Calcium signaling mechanisms in T lymphocytes. Annu Rev Immunol. 2001;19:497-521.

33. van der Geest KS, et al. Low-affinity TCR engagement drives IL-2-dependent post-thymic maintenance of naive $\mathrm{CD} 4^{+} \mathrm{T}$ cells in aged humans. Aging Cell. 2015;14(5):744-753.

34. Mackall CL, Fry TJ, Gress RE. Harnessing the biology of IL-7 for therapeutic application. Nat Rev Immunol. 2011;11(5):330-342.

35. Dardalhon V, et al. IL-7 differentially regulates cell cycle progression and HIV-1-based vector infection in neonatal and adult $\mathrm{CD} 4^{+} \mathrm{T}$ cells. Proc Natl Acad Sci U S A. 2001;98(16):9277-9282.

36. Swainson L, Kinet S, Mongellaz C, Sourisseau M,
Henriques T, Taylor N. IL-7-induced proliferation of recent thymic emigrants requires activation of the PI3K pathway. Blood. 2007;109(3):1034-1042.

37. Ernst B, Lee DS, Chang JM, Sprent J, Surh CD.

The peptide ligands mediating positive selection in the thymus control $\mathrm{T}$ cell survival and homeostatic proliferation in the periphery. Immunity. 1999;11(2):173-181.

38. Goldrath AW, Bevan MJ. Low-affinity ligands for the TCR drive proliferation of mature $\mathrm{CD}^{+} \mathrm{T}$ cells in lymphopenic hosts. Immunity. 1999;11(2):183-190.

39. Dooley J, Erickson M, Gillard GO, Farr AG. Cervical thymus in the mouse. JImmunol. 2006;176(11):6484-6490.

40. Terszowski G, et al. Evidence for a functional second thymus in mice. Science. 2006;312(5771):284-287.

41. Yang S, Fujikado N, Kolodin D, Benoist C, Mathis D. Immune tolerance. Regulatory T cells generated early in life play a distinct role in maintaining self-tolerance. Science. 2015;348(6234):589-594.

42. Alpdogan O, et al. Keratinocyte growth factor (KGF) is required for postnatal thymic regeneration. Blood. 2006;107(6):2453-2460.

43. Min D, et al. Protection from thymic epithelial cell injury by keratinocyte growth factor: a new approach to improve thymic and peripheral T-cell reconstitution after bone marrow transplantation. Blood. 2002;99(12):4592-4600.

44. Okamoto Y, Douek DC, McFarland RD, Koup RA. Effects of exogenous interleukin-7 on human thymus function. Blood. 2002;99(8):2851-2858.

45. van den Brink MR, Alpdogan O, Boyd RL. Strategies to enhance T-cell reconstitution in immunocompromised patients. Nat Rev Immunol. 2004;4(11):856-867.

46. Halnon NJ, Cooper P, Chen DY, Boechat MI, Uittenbogaart $\mathrm{CH}$. Immune dysregulation after cardiothoracic surgery and incidental thymectomy: maintenance of regulatory $\mathrm{T}$ cells despite impaired thymopoiesis. Clin Dev Immunol. 2011;2011:915864.

47. Li H, Durbin R. Fast and accurate short read alignment with Burrows-Wheeler transform. Bioinformatics. 2009;25(14):1754-1760.

48. Jiang H, Wang F, Dyer NP, Wong WH. CisGenome Browser: a flexible tool for genomic data visualization. Bioinformatics. 2010;26(14):1781-1782.

49. Anders S, Huber W. Differential expression analysis for sequence count data. Genome Biol. 2010;11(10):R106. 